\title{
PEMETAAN WILAYAH BAHAYA BANJIR DI KOTA SUNGAI PENUH
}

\author{
Sisva Yetty $^{1)}$, Drs Helfia Edial, MT ${ }^{2)}$, Triyatno,S.Pd,M.Si ${ }^{2)}$ \\ Jurusan Geografi, \\ Fakultas Ilmu Sosial Universitas Negeri Padang \\ Email: $\underline{\text { Sisvayettyfa@gmail.com }}$
}

\begin{abstract}
Abstrak
Penelitian ini bertujuan untuk, 1) mengetahui tingkat bahaya banjir di Kota Sungai Penuh. 2) mengetahui Persebaran dan luas area bahaya banjir di Kota Sungai Penuh. 3) mengetahui distribusi spasial penduduk pada kawasan bahaya banjir di Kota Sungai Penuh. Penelitian ini merupakan penelitian kuantitatif dengan menggunakan pembobotan atau skoring. Luas wilayah peta administrasi di overlay dengan peta bahaya banjir, untuk menghitung distribusi penduduk $=$ jumlah penduduk $/$ jumlah piksel permukiman dalam administrasi. Temuan penelitian ini adalah wilayah tidak bahaya banjir dengan luas 12.343 ha (34\%), bahaya banjir sedang dengan luas 4.276 ha (53\%), bahaya banjir 4.276 ha (12\%) sangat bahaya banjir dengan luas 505 ha dengan persentase (2\%). Distribusi penduduk berdasarkan kelas sangat bahaya terdapat di Kecamatan Hamparan Rawang 13.384 jiwa dan yang paling rendah berada di Kecamatan Sungai Penuh 1.000 jiwa dalam bahaya banjir.
\end{abstract}

\section{Kata Kunci : Bahaya Banjir, Overlay, Distribusi Spasial Penduduk}

\begin{abstract}
This research of aims are 1) to know the hazard of flooding in Sungai Penuh. 2). Knowing spatial distibution and area flood hazard in Sungai Penuh. 3). To know spatial distribution of the population in the area of the hazard of flooding in Sungai Penuh. This research is quantitative research using weighting or skoring. Calculating area of hazard flooding in Sungai Penuh the overlay map of the administration with the flood hazard map, the distribution of the population = population / number of pixels in administrastion. The result of the research are 12,343 ha (34\% no hazard of flooding area, 4,276 ha (53\%) medium of hazard, 4,276 ha (12\%) hight of hazard flooding and 505 ha (2\%) very hight of hazard flooding. Population distribution based on class is very hazard, there are in Hamparan Rawang District 13,384 population and the lowest is in Sungai Penuh District 1,000 population in hazard flooding.
\end{abstract}

Keywords: Flood Hazard, Overlay, The Spatial Distribution of The Population

\footnotetext{
${ }^{1)}$ Mahasiswa Program Studi Geografi Universitas Negeri Padang untuk wisuda september 2018

${ }^{2)}$ Dosen Geografi Fakultas IImu Sosial Universitas Negeri Padang
} 
PENDAHULUAN

Indonesia merupakan salah satu negara dengan tingkat kerawanan yang tinggi terhadap berbagai ancaman bencana alam. Bencana alam seperti bencana banjir, tanah longsor, dan degradasi lahan memiliki frekuensi kejadian yang sangat tinggi di Indonesia. Posisi geografis Indonesia di daerah tropis terletak antara dua benua dan dua samudera menjadikan Indonesia memiliki sistem cuaca dan iklim kontinen maritim yang khas. Meskipun pola iklim terjadi pergiliran teratur seperti bergantian musim hujan dan musim kemarau, jika terjadi gangguan tropis, sering timbul cuaca ekstrim yang dapat memicu terjadinya bencana alam (Hermon, 2012).

Bencana alam seperti banjir harus mendapatkan perhatian khusus, karena bencana tersebut menyebabkan kerusakan, baik dari kerusakan lingkungan alam maupun non alam (Kingma 1990). Lingkungan merupakan lingkungan yang sangat dinamis dengan berbagai penggunaan lahan yang sangat komplek (King dan Marfai 2008: Aerts et al,2009: Marfai 2011)

Bencana banjir merupakan aspek hubungan manusia dengan alam langsung yang timbul dari proses dimana manusia membutuhkan alam dan memanfaatkan dan menghidari alam yang merugikan manusia sendiri (Suwardi, 1990)
Bencana banjir adalah peristiwa atau rangkaian peristiwa yang mengancam kehidupan dan penghidupan masyarakat yang disebabkan oleh faktor alamiah akibatnya buffer zone pada kawasan upper das (daerah aliran sungai) sehingga mengakibatkan timbulnya korban jiwa manusia, kerusakan lingkungan, kerugian harta benda, dan dampak psikologis. (Hermon, 2012)

Faktor alam yang sangat mempengaruhi adalah curah hujan yang mana ada unsur iklim yang sangat dominan yang mempengaruhi aliran permukaan dan erosi, sifat hujan yang mempengaruhi kenetik hujan yang merupakan penghancur agregat tanah. (Hillel 1971). Melihat dampak terhadap timbulnya bencana banjir yang sering terjadi di Kota Sungai Penuh maka di perlukan survey dan pemetaan untuk menentukan dimana terdapat zona bahaya banjir di Kota Sungai Penuh untuk mengantisipasi kerugian yang dapat diakibatkan bencana banjir. Resiko dan dampak terhadap timbulnya bahaya banjir yang sering terjadi di Kota Sungai Penuh dapat dikurangi atau diminimalkan dengan melakukan kesiapan dan pencegahan terhadap bahaya banjir. Salah satu yang dilakukan adalah mengenal dan mengetahui wilayah yang berpotensi banjir. (Hendri Dede Putra. 2016 ,http://www.kerincigoogle.com/201 
6/04/sungai-penuh-dikepun banjirdan.html)

Kota Sungai Penuh dengan peningkatan jumlah penduduk dari tahun 2010 dengan 82.619 jiwa, pada tahun 2014 terjadinya peningkatan dengan jumlah penduduk 86.220 jiwa dan terjadinya peningkatan jumlah penduduk 87.132 jiwa (BPS Kota Sungai Penuh 2016).

Terjadinya peningkatan jumlah penduduk maka membawa dampak kepada peningkatan lahan dan permintaan akan pemenuhan kebutuhan pelayanan dan prasarana kota juga berdampak menurunnya kualitas lingkungan seperti seperti degradasi lingkungan dan bencana alam. Salah satu permasalah yang sering terjadi setiap tahunnya adalah masalah banjir. Hampir setiap tahun bencana banjir di Kota Sungai Penuh terjadi pada setiap musim penghujan. Penelitian ini bertujuan untuk mengetahui bahaya banjir di Kota Sungai Penuh, untuk mengetahui Persebaran dan luas area bahaya banjir di Kota Sungai Penuh, serta mengetahui distribusi spasial penduduk pada kawasan bahaya banjir di Kota Sungai Penuh.

\section{Bahaya Banjir}

Bencana alam yang semakin meningkat seperti, badai, hujan dengan intesitas tinggi dalam waktu yang pendek. Umumnya sangat berpengaruh tehadap banjir yang merupakan keadaan dimana didalam saluran yang melampaui kapasitas daya tampung yang ada (Larsen et.al. 2001). Bahaya adalah segala kondisi yang dapat merugikan baik materi maupun non materi atau bahaya adalah sumber, situasi, tindakan yang berpotensi menciderai manusia, penyakit atau kombinasi dari semuanya (OHSAS 18001: 2007) .

Floods are one of the most wide-reaching and commonly occurring natural hazard in the world, affecting an averge about 70 million people each year (Suminski, 2013) dalam pernyataan tersebut, peneliti mengatakan bahwasanya banjir merupakan salah satu bencana yang paling luas jangkauannya. Banjir adalah fenomena alam yang sumbernya dari hujan dengan intensitas yang tinggi dan memlikik durasi lama pada daerah aliran sungai (DAS).

Pemetaan bahaya banjir merupakan penyajian daerah-daerah yang secara fisik merupakan daerah sasaran banjir. Banjir yang terjadi berulang-ulang akan meninggalkan bekas sebagai bentuk lahan hasil bentukan proses banjir, yang mempunyai sifat khusus terutama material penyususunnya. Pemetaan daerah bahaya banjir ini bertujuan untuk mengidentifikasi daerah mana saja yang berpotensi untuk terjadinya banjir, sehingga daerah tersebut dapat dianalisis untuk melakukan pencegahan dan penanganan banjir (Prasasti dkk, 2015). 
Bahaya banjir merupakan keadaan yang menggambarkan suatu ancaman mudah atau tidaknya suatu daerah terkena banjir. Bahaya banjir merupakan suatu aspek yang interaksi antara manusia dan akan muncul dari proses yang telah umum terjadi, dimana manusia pada umumnya mencoba mencari dan memanfaatkan alam yang menguntungkan dan menajauhi alam yang membahayakan bagi kehidupan mereka.Hubungan hidrometeorologi dan ilmu sosial sangat erat dimana bisa diketahui dan pada dasarnya dalam mengahadapi bahaya banjir terdapat pendekatan, memperkuat diri dengan membuat tanggul penahan, memperkuat bangunan, menghindari daerah bahaya dengan mencari daerah yang relatif aman misalnya tidak berada di dataran rendah atau dataran aluvial (Montz, 2002). Adapun dampak bahaya banjir bagi aktivitas sosial ekonomi a) gangguan terhadap kawasan kota, b) gangguan terhadap sarana dan prasarana seperti jaringan jalan, c) gangguan terhadap permukiman penduduk, d) penggurangan produktifitas lahan pertanian, e) peningkatan wabah penyakit (Nicholls et al.2000)

\section{METODE PENELITIAN}

DEM berfungsi sebagai menampil kan informasi ketinggian atau elevasi daerah penelitian (Kresch et al. 2002) Dem yang berasala dari titik ketinggian permukaan tanah dari peta RBI. Data elevasi bersifat sebagian sehingga setiap titiknya di permukaan tanah (Milis et al.2005)

Jenis penelitian ini adalah penelitian kuantitatif. dengan Metode yang digunakan untuk pemetaan bahaya banjir dengan menggunakan skoring dan untuk luas wilayah dengan overlay peta administrasi dengan peta bahaya banjir dan untuk menghitung distribusi penduduk dengan menggunakan Distribusi pendududuk $=$ Jumlah penduduk $/$ piksel permukiman dalam administrasi (Mutaali Lutfi, 2012)

Data

Data yang digunakan dalam penelitian ini data citra Spot 6 tahun 2015 dilakukan pengolahan data klasifikasi penggunaan lahan. Data DEM untuk analisis kondisi wilayah atau topografi, land system juga digunakan sebagai salah satu input dalam pembuatan pemetaan bahaya banjir. Variabel yang diteliti dalam penelitian ini adalah :Curah Hujan , Lereng, Penggunaan lahan, Sistem Lahan

\section{Daerah Penelitian}

Penelitian dilakukan di Kota Sungai Penuh, Provinsi Jambi

\section{HASIL DAN PEMBAHASAN}

Pemetaan wilayah bahaya banjir

\section{Topografi}

\begin{tabular}{rrrr}
\multicolumn{2}{c}{ Kemiringan } & lereng & wilayah \\
Kota & Sungai & Penuh & sangat
\end{tabular}


bervariasi, dapat dibagi menjadi klasifikasi lereng yang datar, berombak, agak curam, curam, sangat terjal.

Sebagian besar wilayah yang agak curam,curam, dan sangat terjal terdapat di kawasan perbukitan yang terdapat di Kecamatan Sungai Bungkal, Kecamatan Kumun, dan Kecamatan Pondok Tinggi Sedangkan untuk dataran datar dan berombak terdapat di sebagian besar daerah Kecamatan Hamparan Rawang dan Tanah Kampung, serta di Kecamatan Pesisir Bukit, Sungai Penuh dan Kumun bagian timur.

\section{Cuaca}

Kota Sungai Penuh dengan curah hujan rata-rata mencapai 31 $\mathrm{mm} / \mathrm{thn}$. Dengan suhu minimum sebesar $21^{\circ} \mathrm{C}$ dan suhu maksimum mencapai $29,1^{\circ} \mathrm{C}$.

\section{Penggunaan lahan}

Penggunaan lahan merupkan hasil aktivitas manusia terdapat sumber daya guna mencukupi kebutuhan hidupnya, yang terdapat interaksi antara manusia dengan sumber daya alam, sehingga akan membawa suatu perubahan terhadap lahan dan lingkungan.

\section{Sistem Lahan ( Land System)}

Sistem lahan atau land system merupakan area yang mempunyai pola yang berulang dari topografi, tanah, vegetasi. Kriteria sistem lahan Kota Sungai Pemuh dengan klasifikasi penggunungan dengan luas 27.298 Ha, bukit dengan luas 4.683 ha, dataran bergelombang 457 ha, dan dataran aluvial 4.048 ha.

\section{Pemetaan Wilayah Bahaya Banjir}

Kriteria Klasifikasi tingkat bahaya banjir diperoleh dari hasil penjumlahan skor peta yang di overlay. yaitu kelas tidak bahaya dengan 100 - 200, cukup Bahaya 201 - 300, Bahaya 301 - 400, Sangat Bahaya 401 - 500, maka berdasarkan hasil pengolahan data tingkat bahaya banjir di Kota Sungai Penuh dapat dilihat pada tabel 1.

Tabel 1. Kelas Bahaya Banjir Di Kota Sungai Penuh

\begin{tabular}{|c|l|l|}
\hline No & Interval & \multicolumn{1}{|c|}{ Kelas Bahaya Banjir } \\
\hline 1 & $100-200$ & Tidak Bahaya \\
\hline 2 & $201-300$ & Bahaya Sedang \\
\hline 3 & $301-400$ & Bahaya \\
\hline 4 & $401-500$ & Sangat Bahaya \\
\hline \multicolumn{3}{|c|}{ Sumber : hasil pengolahan data 2017 }
\end{tabular}

Tingkat bahaya banjir di Kota Sungai Penuh adalah tidak Bahaya dengan luas $12.343 \mathrm{Ha}$ (34\%) dikatakan tidak bahaya karena skoring hasil overlay adalah antara $100-200$ dengan penggunaan lahan hutan yang memiliki jenis potensi infiltrasi yang tinggi, lereng yang terjal (>45) curah hujan 100 - $200 \mathrm{~mm} / \mathrm{bln}$, sistem lahan dengan kriteria pengunungan, sehingga berdasarkan variabel diatas wilayah ini termasuk dengan potensi untuk terjadinya banjir dan termaksud dalam kriteria tidak Bahaya.

Bahaya Sedang dengan luas 19.235 $\mathrm{Ha}(53 \%)$ dikatakan 
bahaya karena skoring hasil overlay adalah 201 - 300, dengan penggunaan lahan semak belukar , lereng yang curam (25 - 45) curah hujan 100 - $200 \mathrm{~mm} / \mathrm{bln}$, sistem lahan dengan kriteria bukit, sehingga berdasarkan variabelnya wilayah ini termasuk wilayah dengan potensi terjadinya kecil dan lebih bahaya dibandikan dengan sebelumnya serta tergolong bahaya sedang. Untuk kriteria bahaya 4.276 Ha $(12 \%)$ dikatakan bahaya karena skoring hasil overlay adalah 301 400, dengan penggunaan lahan sawah, lereng yang berombak (8 15) curah hujan $200-300 \mathrm{~mm} / \mathrm{bln}$, sistem lahan dengan kriteria dataran bergelombang, sehingga berdasarkan variabel diatas wilayah ini termasuk wilayah dengan potensi terjadinya cukup tinggi dan tergolong bahaya.

Sangat bahaya dengan luas 505 ha dengan persentase (2\%) dikatakan bahaya karena skoring hasil overlay adalah 401 - 500 , dengan penggunaan lahan permukiman/lahan terbuka, lereng yang landai $(0-8)$ curah hujan 200 - $300 \mathrm{~mm} / \mathrm{bln}$, sistem lahan dengan kriteria Dataran Aluvial/ Rawa, sehingga berdasarkan variabelnya wilayah ini termasuk wilayah yang berpotensi terjadinya banjir sangat tinggi dan tergolong sangat bahaya. Untuk klasifikasi tingkat bahaya banjir di Kota Sungai Penuh bisa di lihat pada tabel 2 dan gambar 1.
Tabel 2 . Klasifikasi Tingkat Bahaya Banjir di Kota Sungai Penuh

\begin{tabular}{|c|c|c|c|}
\hline No & $\begin{array}{c}\text { Kelas } \\
\text { Bahaya }\end{array}$ & $\begin{array}{l}\text { Luas } \\
(\mathrm{Ha})\end{array}$ & $\begin{array}{c}\text { Persentase } \\
(\%)\end{array}$ \\
\hline 1 & $\begin{array}{c}\text { Tidak } \\
\text { Bahaya }\end{array}$ & 12.343 & $34 \%$ \\
\hline 2 & $\begin{array}{l}\text { Bahaya } \\
\text { Sedang }\end{array}$ & 19.235 & $53 \%$ \\
\hline 3 & Bahaya & 4.276 & $12 \%$ \\
\hline 4 & $\begin{array}{l}\text { Sangat } \\
\text { Bahaya }\end{array}$ & 505 & $2 \%$ \\
\hline \multicolumn{2}{|c|}{ Jumlah } & 36.359 & 100 \\
\hline
\end{tabular}

Sumber: Hasil Pengolahan Data Sekunder tahun 2017

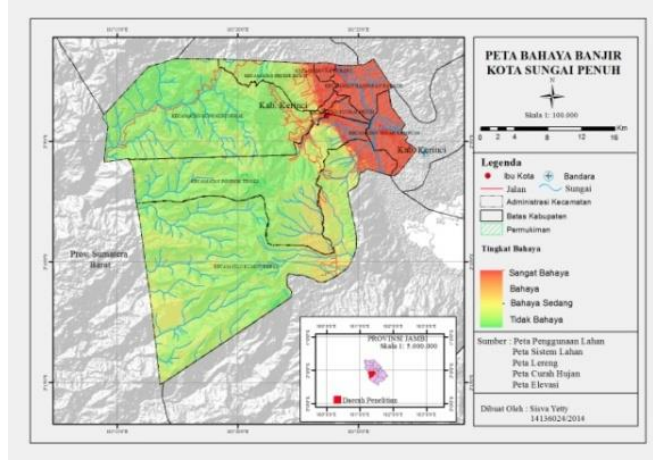

Gambar 1. Peta bahaya Banjir di Kota Sungai Penuh

\section{Persebaran dan Luas bahaya banjir}

Berdasarkan hasil overlay luas bahaya banjir berdasarkan tingkat, sangat bahaya dengan luas $505 \mathrm{Ha}$ yang tersebar didaerah Kota Sungai Penuh sendiri dengan persentase $2 \%$, untuk kelas bahaya sendiri dengan luas 4.276 Ha dengan persentase $12 \%$, untuk kelas bahaya sedang dengan luas area bahaya banjir 19.235 Ha dengan persentase $53 \%$ sedangkan untuk kelas tidak bahaya sendiri seluas $12.343 \mathrm{Ha}$ dengan persentase $34 \%$. 
3. Distribusi Penduduk Terpapar

Berdasarkan hasil dari distribusi pada Kecamatan Koto Baru penduduk yang terpapar sebanyak 19 jiwa disetiap piksel, Kecamatan Pesisir Bukit sebanyak 9 jiwa disetiap piksel, Kecamatan Hamparan Rawang sebanyak 8 jiwa disetiap piksel, Kecamatam Tanah Kampung sebanyak 5 jiwa disetiap piksel, pada Kecamatan Pondok Tinggi terdapat 10 disetiap piksel, pada Kecamatan Sungai Penuh terdapat 8 jiwa disetiap piksel, untuk kecamatan Kumun Debai terdapat 7 jiwa disetiap piksel dan Kecamatan Sungai Bungkal terdapat 12 jiwa disetiap piksel. Untuk Distribusi Penduduk Berdasarkan Jumlah Penduduk Per Piksel Permukiman Kota Sungai Penuh bisa dilihat pada tabel 3.

Tabel 3. Distribusi Penduduk Berdasarkan Jumlah Penduduk Per Piksel Permukiman Kota Sungai Penuh

\begin{tabular}{|c|l|c|}
\hline No & \multicolumn{1}{|c|}{ Kecamatan } & Jiwa \\
\hline 1 & Kecamatan Koto Baru & 19 \\
\hline 2 & Kecamatan Pesisir Bukit & 9 \\
\hline 3 & Kecamatan Tanah Kampung & 5 \\
\hline 4 & $\begin{array}{l}\text { Kecamatan Hampara } \\
\text { Rawang }\end{array}$ & 8 \\
\hline 5 & Kecamatan Pondok Tinggi & 10 \\
\hline 6 & Kecamatan Sungai Penuh & 8 \\
\hline 7 & Kecamatan Kumun Debai & 7 \\
\hline 8 & Kecamatan Sungai Bungkal & 12 \\
\hline \multicolumn{2}{|l}{ Sumber: Pengolahan Data Sekunder } \\
\hline
\end{tabular}

Distribusi penduduk berdasarkan kelas bahaya

Dimana untuk disribusi penduduk berdasarkan kelas sangat bahaya terdapat di Kecamatan Hamparan Rawang dimana 13.384 jiwa yang terdistribusi pada kelas sangat bahaya dan untuk distribusi terendah terdapat di Kecamatam Sungai Penuh yang mana 1.000 jiwa yang berada dalam klasifikasi sangat bahaya banjir.

Untuk klasifikasi kelas bahaya sendiri terdapat di Kecamatan Pondok Tinggi yang tinggi jumlah jiwa yang 17.650 jiwa yang terdistribusi kelas bahaya banjir sendiri dan untuk yang terendah di Kecamatan berada pada Kecamatan Tanah Kampung 7.995 jiwa yang terdistribusi pada kelas bahaya tersebut.

Untuk klasifikasi kelas bahaya sedang sendiri terdapat di Kecamatan Sungai Bungkal yang tinggi jumlah jiwa yang mana terdapat 1476 jiwa yang terdistribusi kelas bahaya sedang dan untuk yang terendah dikecamatan berada pada Kecamatan Pondok Tinggi 150 jiwa yang terdistribusi pada kelas bahaya sedang tersebut.

\section{PENUTUP}

\section{Kesimpulan}

Berdasarkan hasil penelitian dan pembahasan dimana terdapat kelas tidak bahaya banjir di Kota Sungai Penuh adalah tidak Bahaya dengan luas $12.343 \mathrm{Ha}$, Bahaya Sedang dengan luas 4.276 Ha, bahaya 4.276 Ha, Sangat bahaya dengan luas 505 ha.

Untuk distribusi penduduk berdasarkan kelas sangat bahaya terdapat yang paling tinggi terdapat di Kecamatan Hamparan Rawang 
13.384 jiwa dalam bahaya banjir dan yang paling rendah berada di Kecamatan Sungai Penuh 1.000 jiwa dalam bahaya banjir.

\section{Saran}

a. Untuk pemerintahan Kota Sungai dan instansi terkait untuk dapat mengkaji kembali pola ruang yang direncanakan dan dikaitkan dengan keadaan persebaran bahaya banjir.

b. Pemerintah daerah perlu meningkatkan kegiatan sosialisasi tentang bahaya banjir dan dampak yang diakibatkan oleh banjir terhadap aktivitas masyarakat, meningkatkan kesadaran akan peduli terhadap lingkungan, nenambah dan memperbaiki infrastruktur-insfratruktur yang berkaitan dengan banjir.

c. Pemerintahan Kota Sungai Penuh dan Instansi terkait untuk dapat lebih mengawasi pelaksanaan pengembangan permukiman untuk menghindari pengembangan permukiman dilakukan pada daerah yang tidak potensial untuk dikembangkan terutama pada daerah bahaya banjir.

\section{DAFTAR PUSTAKA}

[BPS] Badan Pusat Statistik. 2016. Kota Sungai Penuh Dalam Angka 2016. BPS Kota Sungai Penuh. Kota Sungai Penuh.

Hermon, Dedi. 2012. Mitigasi bencana

Hidrometeorologi. UNP Press Padang. Padang
Hendri Dede Putra. 2016 , http://www.kerincigoogle.co $\mathrm{m} / \quad$ 2016/04/sungaipenuh-dikepung banjirdan.html

Hillel D. 1971. Soil and Water ,New York. Academic Press.

Kingma N.C. 1990. Natural Hazard : Geomorpholgyical Aspect of Floodhazard. ITC, The Netherlands Vol 12. 258. 232-324

King, L.and Marfai, M.A 2008." ,Tidal Indundation Mapping Under Enchanced Land Subsidence in Semarang. Thesis ITC, Enschade, , The Netherlands. Vol 11. 3042010 pp 124-129

Kresch, et al 2012: Fifty Year Flood Inundation Maps For Olanchito Honduras

Tacoma, Wahitong, USA, US Geological Survey.Vol 13, 221-241

[OHSAS]. 2007 Occopational Health and Safety

Management System. Vol 2 20815 pp: 416

Perka : Peraturan

Kementrian Pekerjaan Umum no 22 tahun 2007

Prasasti,dkk 2015. Analisis dan Pemetaan Daerah Rawan Banjir di Kota Makasar Berbasis Spatial. Vol 4. 35 2009

Larsen, M.C, Conde, M.T.V, Clark, R.A, 2001, Landslide Hazards Associeted with Flash-Floods, With Examples from the Dexember,1999 Disaster in Vanezuela, Coping With Flash Floods, Kluwer Academic Publisher. Jurnal Sains dan 
Teknologi Indonesia. Vol 15.1 042013 pp 259-275

Marfai, M.A, 2003, GIS modelling of river and tidal Hazard in a waterfront City, Case Study, Semarang City, Central Java, Indonesia Thesis Master of Science International Institute for Geo-infomation Science and Earth Observation, ITC the Netherlands. Vol 18. 412 2006 pp 132-145

Mutaali Lutfi. 2012. Daya Dukung Lingkungan Untuk Perencanaan Pembangunan Wilayah. BPFG UGM. Yogyakarta Mills, J.P,: Buckely, S.j Mitchell, H.L 2005. “ $A$ geomatics data integration technique for coastal change monitoring. Earth Suface Processes and Landform. Vol 4. 14675 pp 210-143.

Montz,B E .2002. Flash Flood Mitigation: Recommendations for reasearch and Aplications. Journal of Environmental Hazards 4 (2002) Pergamon Vol 15.1042013 pp 15-22.

Nicholls, J.R dan Mimura, N 2000 : Regional issues raised by sea level rise and their Policy Implications". Climate Reasearch, Vol 1, 5-18.

Suwardi. 1990. Identifikasi Dan Pemetaan Kawasan Rawan Banjir di Sebagian Kotamadya Semarang dengan Menggunakan Sistem Informasi Geografis[ Tesis]. Bogor : Program Pasca Sarjana, Institut Pertanian Bogor. Vol 424 06: 7-9
Suminski, Swenja. 2013. The role of Insurance in Reducing Direct Risk. The Case of Flood Insurance. Senior Research Fellow, Grantham Researh Institute, London School of Economic, London. UK. International Review of Enviromental and Resource Economics. Vol 7, 241-278 